\title{
University-industry technology transfer: a systems approach with policy implications
}

\author{
Cory R.A. Hallam*
}

Department of Entrepreneurship and Technology Management,

College of Business,

The University of Texas at San Antonio,

One UTSA Circle, San Antonio, TX 78249, USA

Email: cory.hallam@utsa.edu

*Corresponding author

\section{Bernd Wurth}

Department of Management Science,

University of Strathclyde Business School,

40 George Street, Glasgow G1 1QE, UK

Email: bernd.wurth@strath.ac.uk

\section{Ruben Mancha}

Department of Business Administration,

School of Business,

Trinity University,

One Trinity Place, San Antonio,

TX 78212-7200, USA

Email: rmancha@trinity.edu

\begin{abstract}
The purpose of this paper is to provide a systems perspective of the university-industry technology transfer (UITT) process. Departing from the traditional linear approach to technology transfer, we build a model capturing interactions between a selected number of technology transfer channels and variables endogenous to the technology transfer process. The relationships identified in the model demonstrate that the UITT process and its impact extend well beyond the traditional scope of the university technology transfer offices. A narrow view of the process, one focused on short-term revenue maximisation principles, is inadequate due to secondary system elements that can impact technology commercialisation outcomes. The model suggests, when deciding on licensing, consulting or collaborative research agreements, universities should account for their reputation for technology transfer and R\&D as key assets. We show that a technology transfer policy that relaxes licensing terms in favour of industry can have multi-path positive feedbacks on university success.
\end{abstract}

Keywords: university-industry technology transfer; UITT; technology transfer office; TTO; system dynamics; licensing; policy. 
Reference to this paper should be made as follows: Hallam, C.R.A., Wurth, B. and Mancha, R. (2014) 'University-industry technology transfer: a systems approach with policy implications', Int. J. Technology Transfer and Commercialisation, Vol. 13, Nos. 1/2, pp.57-79.

Biographical notes: Cory R.A. Hallam is the Director of the Center for Innovation and Technology Entrepreneurship (CITE), Chief Commercialisation Officer and Jacobson Distinguished Professor of Innovation and Entrepreneurship at the University of Texas at San Antonio (UTSA). He holds a $\mathrm{PhD}$ in Technology Management and Policy, an MS in Technology and Policy and an MEng in Aeronautics and Astronautics from the Massachusetts Institute of Technology. He has worked as an Engineer and Programme Manager in lean enterprise transformation. His current research efforts focus on lean enterprise transformation, technology innovation and technology entrepreneurship.

Bernd Wurth is a $\mathrm{PhD}$ candidate at the University of Strathclyde, UK. He is affiliated with the Department of Management Science and the Hunter Centre for Entrepreneurship. He holds a BEng in Mechanical Engineering from South Westphalia University of Applied Sciences in Soest, Germany and an MSc in Management of Technology from The University of Texas at San Antonio, USA. His research interests include the dynamics of open innovation, technology transfer and technology-based entrepreneurship as well as innovation ecosystems.

Ruben Mancha is an Assistant Professor in the Department of Finance and Decision Sciences, Trinity University School of Business. He received his PhD in Information Technology from the University of Texas at San Antonio. His research interests include business analytics, business sustainability and simulation. His research has been published in scholarly journals such as Decision Support Systems, Journal of Information Technology Management and Journal of Intelligent Systems in Accounting, Finance and Management.

This paper is a revised and expanded version of a paper entitled 'Building a system dynamics model for understanding the university-industry technology transfer process and the implications for technology transfer office policies' presented at the University-Industry Interaction Conference, Barcelona, Spain, 23-25 April 2014.

\section{Introduction}

According to the Association of University Technology Managers (2014), universities in the US spent $\$ 65.1$ billion on research and development (R\&D) in 2013, a 2.3\% increase with respect to the previous year. The innovations created, added to universities' portfolios of intellectual property (IP), yielded a total of 43,295 licenses and options in 2013 (Association of University Technology Managers, 2014). The increasing number of technologies available for licensing is attractive to companies seeking to grow their product and service offerings. As more firms license innovations from universities, the interest in university innovation creation and technology transfer increases (Chesbrough, 2006). This paints a very positive picture of the university technology licensing process, yet we do not see an unbounded year-to-year increase in privately sponsored research spurring university innovations or in the number of technologies licensed.

Universities have undoubtedly identified licensing growth potential as important in their operations. A growing number of them now include technology transfer in their 
mission, not only as stream of revenue, but also as a means to support their goals of educating people, conducting sponsored research, serving society andpromoting economic development (Carlsson and Fridh, 2002; Rasmussen et al., 2006). However, many universities still focus on the 'traditional' linear model of technology transfer (Bradley et al., 2013), placing too much emphasis on patents and licensing revenue, while disregarding the impact of technology transfer reputation. Among other routes, universities have the opportunity to showcase their innovativeness, improve their reputation and attract more companies to licensing agreements after successful sponsored research collaborations. For example, in 2013, only $\$ 4.58$ billion of the US universities' R\&D budgets (Association of University Technology Managers, 2014), approximately $7 \%$, originated from sponsored research.

The value of the system dynamics approach we describe in this paper stems from the study of the inherent complexity of the university-industry technology transfer (UITT) process. Many studies have explored the linear aspects of the UITT process, including the presence of barriers to technology transfer and offered suggestions for improving it (e.g., Siegel et al., 2003a, 2003b; 2004; Swamidass and Vulasa, 2009; Thursby and Thursby, 2002, 2003). However, from a policy perspective, models evaluating ex ante the effects of technology transfer policy and decisions have not been forthcoming. For executives at university technology transfer offices (TTOs), the key to sustainable success is not only identifying weaknesses in their existing policies and processes, but developing a deeper understanding of the dynamics associated with these policies and how particular policies and strategies influence the behaviour of the overall UITT system. If we adopt the perspective of a TTO, the question to address is: what additional TTO services and firms' perceptual processes result in a successful technology transfer process?

Using a qualitative system dynamics approach on UITT, we capture the complexity of this system and provide a holistic view for researchers and TTO management alike. We identify and model four interacting channels affecting the outcomes of the university technology-transfer process, namely: licensing, collaborative research, academic entrepreneurship and consulting. In addition, by applying a resource-based view of the UITT process, we account for factors such as the universities' reputation. Industry perceptions of TTO flexibility and bureaucracy, which industry identifies as an issue and most TTO personnel fail to ascertain as relevant to successful UITT (Siegel et al., 2003a), are incorporated into our system dynamics model. Our hypothesis is that a TTO creating policy with the sole objective of short-term revenue maximisation will obtain sub-optimal returns. Furthermore, system dynamics modelling shifts the description of the UITT process from the current TTO focus on control, operating under the premises of agency theory (Eisenhardt, 1989), to a broader perspective incorporating implicit and explicit relationships with stakeholders (Hill and Jones, 1992).

This paper marks a first step towards the comprehensive modelling and simulation of university technology transfer. Systems modelling, at this stage, is employed to establish a common understanding of the inner workings of the technology transfer process, preceding simulation experiments (Forrester, 2007; Pidd, 2009). With this goal in mind, we first provide an overview of the role of university TTOs, followed by an overview of our modelling approach. Then, we build and evaluate a comprehensive UITT model investigating the presence of reinforcing and balancing elements. To bring the manuscript to a close, we present a detailed discussion of the impact of alternative TTO policies and offer conclusions and directions for future research that supports the stakeholder-agency theory approach (Hill and Jones, 1992). 


\section{The role of TTOs}

There are three main parties involved in the university technology transfer process, namely: the university researcher, the university TTO acting as the contracting intermediary and the established company or entrepreneur licensing or commercialising the technology (Siegel et al., 2003a). Throughout this manuscript, our main focus is on the TTO. Most large US universities have well-established TTOs (Friedman and Silberman, 2003), yet their size and the scope of services they offer vary. In some cases, TTOs have been renamed using terms like offices of commercialisation, innovation, outreach, knowledge exchange, or industry engagement (Bradley et al., 2013). We use the name TTO throughout this paper as representative of all of these, although we acknowledge that the process is not a one-way transfer and there exists a capacity for bidirectional exchange of knowledge, information and technology between the university and its industry partners (Martinelli et al., 2008).

Bercovitz et al. (2001) describe the main activities of TTOs as handling invention disclosures, licensing university IP and initiating collaborative research agreements. The first two activities are covered by the traditional linear model of technology transfer (Harmon et al., 1997). Figure 1 provides an overview of the different steps and stakeholders involved in the traditional linear model of technology transfer.

Figure 1 Traditional linear model and stakeholder involvement

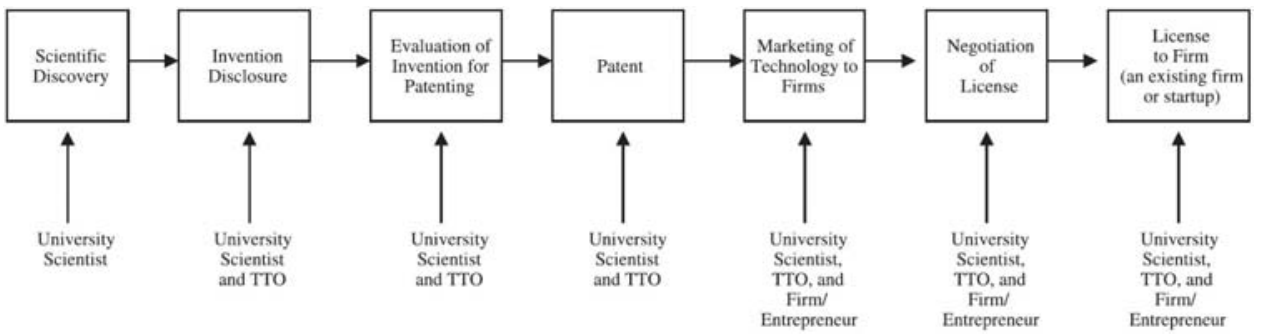

Source: Siegel et al. (2003a)

In the traditional linear theory, the process starts with a scientific discovery made by a researcher (Siegel et al., 2003b). The TTO relies on the researchers' willingness to disclose their inventions, which is affected by the incentive structure defined by the university (Aldridge and Audretsch, 2010; Jensen et al., 2003; Owen-Smith and Powell, 2001). Once the invention disclosure occurs, the TTO is involved in every step until the license agreement is signed.

After a new disclosure is made to the TTO, its personnel must evaluate the potential and estimate the monetary value, or potential for return of the innovation (Siegel et al, 2003b). For these steps to be successful, TTO staff must have a deep understanding of the industry and the potential licensees or buyers for the technology. Since patent applications are expensive and TTOs have limited resources for patenting (Kim, 2011), TTO personnel must evaluate whether the potential revenues from a technology exceed the patent investment (Shane, 2004; Siegel et al., 2004). As global patent protection is very expensive (Siegel et al., 2004), TTOs frequently file for a provisional patent and test its marketability (Jensen and Thursby, 2001), or limit submission to a domestic patent application (Siegel and Phan, 2005). 
Once the patent application has been filed, the TTO immediately starts to market the technology (Siegel and Phan, 2005). Markman et al. (2005) reported that the faster a TTO can commercialise patent-protected technologies, the greater the licensing revenues streams will be. According to their study, speed is influenced by the TTO's resources and structure, their knowledge of the industry in the particular field and faculty involvement throughout the process. Marketing of technologies becomes even more important if the university does not have a tier one reputation, as companies and entrepreneurs pay less attention to its IP portfolio (Siegel et al., 2004).

From an information economics perspective (Nelson, 1959; Cohen and Levinthal, 1990) firms are better informed about market opportunities, which results in information asymmetry in technology licensing markets (Balakrishnan and Koza, 1993). In fact, universities are typically poorly informed about markets in general and face an adverse selection problem: the potential licensee may claim that a patent has a low commercial value to obtain it at a low price (Macho-Stadler and Pérez-Castrillo, 2010). If the university is better informed than the firm about the value of an innovation, it can use royalties to signal its value (Gallini and Wright, 1990; Macho-Stadler and Pérez-Castrillo, 1991). Under fixed payment agreements, the TTO receives the money up front, independently of the firm's revenues, while under variable payment agreements (e.g., royalty) the amount depends on the firm's productivity. Hence, the use of royalty licensing signals a high-quality innovation (Bercovitz and Feldmann, 2006; Macho-Stadler and Pérez-Castrillo, 2010). In order to mitigate the impact of information asymmetry, some licensing strategies combine fixed and variable payments to favour risk sharing between the two parties (Lowe, 2006).

Traditionally, for the university, licensing revenue is tracked as one of the most important outputs of the UITT process and one of the central goals of its TTO (Jensen and Thursby, 2001; Association of University Technology Managers, 2014). TTOs apply a wide range of strategies to achieve this result. While some TTOs focus on transferring more knowledge and IP to the industry, other focus their resources to commercialise few 'homerun' technologies (Litan et al., 2007), which promise high returns within a short amount of time and are usually licensed or sold to high technology industries (Lerner, 2005). Licensing success, in the end, heavily depends on the TTOs communicating with inventors and the capabilities of the TTO staff to accurately estimate the value and market potential of an invention.

The third activity of some TTOs is the initiation of collaborative research projects (Bercovitz et al., 2001). Collaborative research, sometimes called sponsored research, is a form of university-industry partnership that is becoming more relevant, especially as universities face decreasing government research funding (Santoro, 2000; Kealey and Nelson, 1996). Companies are engaging in UITT in an earlier stage, pre-licensing and funding R\&D projects in university laboratories. As Santoro (2000) points out, the complexity of new technologies and the pace of new innovations increases companies' interest in engaging in the early stages of the innovation and technology development process. Lee (2000) reported that these relationships are mutually beneficial, as firms benefit from an increased access to new discoveries and innovations and faculty members benefit from increasing their research funds for graduate students and laboratory equipment and by gaining insight into the application of their research and market pull for their technologies.

Additional technology transfer channels have emerged recently in the UITT literature. We include two of them, namely academic consulting (Bercovitz and Feldman, 2006; 
Cohen et al., 2002) and academic entrepreneurship (Siegel et al., 2007; Wright et al., 2007). Academic consulting can be defined "as the provision of a service by academics to external organisations on commercial terms". This may involve providing advice, resolving technical problems, as well as generating or testing new ideas. "Consulting is usually provided individually by academics" (Perkmann and Walsh, 2008). Universities worldwide often encourage their faculty to get involved in consulting activities, allowing them to commit a percentage of their regular work hours to the activity (Schmoch, 1999). Perkmann and Walsh (2008) define three types of academic consulting: opportunitydriven, motivated by additional income; commercialisation-driven, motivated by technology development; and research driven, motivated by new research opportunities. Most commonly, consulting agreements are reached as the result of personal relationships and the reputation of the researcher. In an expanded view of the TTO, this activity can serve as a facilitator, bringing companies and faculty together.

Academic entrepreneurship has observed significant growth over the past few years. The term itself has even become a buzzword for different kinds of entrepreneurial activities (Siegel, 2013). If the value or potential of a technology is unclear, academic entrepreneurship can be an effective approach to commercialisation (Baycan and Stough, 2013). Entrepreneurship in this context includes the creation of start-ups and spin-offs from the university, often targeted at bridging the gap between research and market and focused heavily on technological risk reduction activities funded by private sources. Bradley et al. (2013) define start-ups as "companies created by licensing an early-stage invention to an independent entrepreneur (who is not necessarily a faculty member), with the goal of developing the company around the growth and commercialisation of the technology". Spin-offs, on the other hand, are "new companies formed by individuals (faculty members) related to the university or university research park to develop a technology that was discovered in and is transferred from, the parent organisation" (Bradley et al., 2013). Siegel et al. (2003c) found that the research productivity of companies within a university research park is higher, compared to companies outside. Geographical proximity of the park to university is also an important factor (Link and Scott, 2005). A crucial success factor for spin-offs is the support from the university and its researchers (Steffensen et al., 2000).

Entrepreneurial activities supported by students can also be considered academic entrepreneurship. Beyond profit maximisation, academic entrepreneurship pursues technology development, public service, economic development and peer-recognition, among other goals (Hayter, 2011).

A TTO by definition plays a role in technology-based economic development, especially in light of technology licenses to regionally-based companies. Furthermore, TTOs can significantly contribute to the development of academic entrepreneurship. Through its wide network of contacts and relying on its expertise in different industries, a TTO can bring together researchers, venture capitalists, advisors and managers (O'Shea et al., 2005). Unfortunately, most TTOs are focused on supporting contractual relations and protecting their IP, rather than seeking involvement in entrepreneurial activities (Clarysse et al., 2011). They follow the traditional linear model of technology transfer, attending to a narrow view of the process, aiming to maximise short-term revenue. This approach, as we demonstrate using system dynamics, is inadequate due to secondary system elements that impact technology commercialisation outcomes arising from the inherent system complexity of stakeholder theory not captured in a linear model (Hill and Jones, 1992). 


\section{System dynamics modelling}

Forrester (1961, p.8) noted that "managing is the task of designing and controlling an industrial system. Management science, if it is to be useful, must evolve effective methods to analyse the principal interactions among all the important components of a company and its external environment". Among a variety of modelling methods, system dynamics remains popular as an interdisciplinary approach used to understand complex, dynamic systems. It is designed to help managers and policy makers deal with changing environments and complex information feedback structures (Sterman, 2000). Key elements of system dynamics are an endogenous point of view and feedback thinking (Richardson, 2011). Forrester (1968, pp.4-2) explained that "in concept a feedback system is a closed system. Its dynamic behaviour arises within its internal structure. Any action which is essential to the behaviour of the mode being investigated must be included inside the system boundary". This means that feedback loops are really a consequence of the endogenous point of view (Richardson, 2011), but also enable the endogenous point of view and give it structure (Richardson, 1999).

System dynamics models can be illustrated by using stock and flow diagrams (or simple flow diagrams) or causal loop diagrams (Pidd, 2004). The terms 'causal loop diagrams' and 'influence diagrams' are sometimes used interchangeably. However, Coyle (1996) explains that even though both diagrams are similar, causal loop diagrams do not include as much details as influence diagrams. One example of the greater level of detail is the distinction between process flows and information flows in influence diagrams. Forrester (1961) introduced the fundamental ideas of stock and flow diagrams, required for quantitative simulation. They are often based on influence diagrams or causal loop diagrams (Coyle, 1998). According to Wolstenholme (1990, p.4), qualitative system dynamics can be characterised as a process:

- to create and examine feedback loop structure of systems using resource flows, represented by level and rate variables and information flows, represented by auxiliary variables

- to provide a qualitative assessment of the relationships between system processes (including delays), information, organisational boundaries and strategy

- to estimate system behaviour and to postulate strategy design changes to improve behaviour.

In the course of this paper, we employ system dynamics theories in modelling the relationships in the UITT process. Such a theoretical approach aims to develop simplified models of reality (Coyle, 1998) to "allow people to think through their own positions and to engage in debate with others about possible action" [Pidd, (2009), p.84].

Influence diagrams (or causal loop diagrams; see Figure 2) are used to illustrate hypotheses or a general overview of a system by creating balancing and reinforcing loops (Parunak et al., 1998). They describe variables and their relationships by linking them with arrows. Each relationship is marked with either a positive or a negative polarity, which is an indicator of the influence of one variable on another (Sterman, 2000). As shown in Figure 2, entirely positive loops are reinforcing loops (marked with an ' $R$ '), resulting in system gain, whereas loops with an odd number of negative relationships between two variables are called balancing loops (marked with a 'B'), resulting in system attenuation. Solid arrows symbolise physical flows, whereas dotted lines represent 
information or actions (Coyle, 1996). We apply this thinking to gain a more comprehensive understanding of the UITT process.

Figure 2 Example of an influence diagram (see online version for colours)

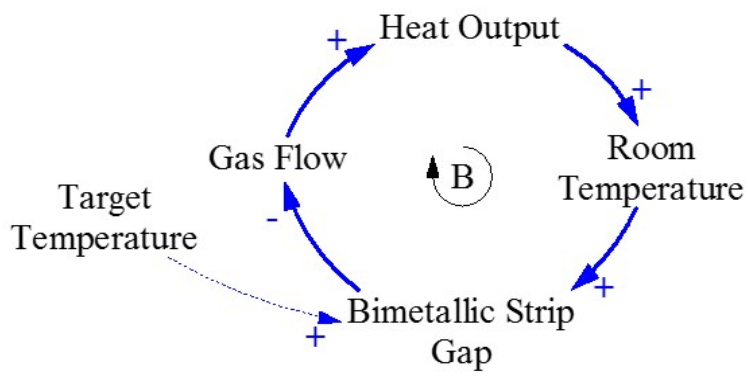

Source: Pidd (2004)

\section{A systems perspective for TTOs}

The traditional linear model of university technology transfer has various limitations and inaccuracies. It oversimplifies the process with a one-size-fits-all approach, places excessive emphasis on patents and fails to account for information mechanisms essential to technology transfer (Bradley et al., 2013). Implicit processes such as the building of a university's technology transfer reputation are also missing in the traditional linear model. The four main technology transfer channels described in Section 2: licensing, collaborative research, academic entrepreneurship and consulting, are modelled and investigated in this section. We focus on the process, analysing the impact of licensing terms and industry's perceptions and ultimately the impact on the university.

\subsection{Licensing}

Bercovitz and Feldmann (2006) define licenses in UITT as "the legal rights to use a specific piece of university intellectual property". The general university-industry technology licensing process has four steps: invention disclosure, patent award, license negotiation and payback to the university according to the license agreement (Carlsson and Fridh, 2002; Chapple et al., 2005; Rogers et al., 2001; Siegel et al., 2003a; Thursby and Kemp, 2002). This process is illustrated in Figure 3.

The steps of the licensing process we contemplate in our systems model are the same as in the traditional linear model (Anderson et al., 2007; Bradley et al., 2013; Siegel et al., 2003a). As a variable, University $R \& D$ represents the research that is performed at a university in terms of dollar amount allocated in the university budget. The more money a university spends on $\mathrm{R} \& \mathrm{D}$, the more patents it will generate and disclosures mediate this process. The system dynamics model does not value the quality of disclosures or patents, so 'homerun' technologies are treated like a standard technology in this first order model. Based on the results of the model development, a spectrum of technologies could be developed based on the quality of the technology, but is not addressed in this paper. 
Figure 3 Influence diagram for university-industry licensing (see online version for colours)

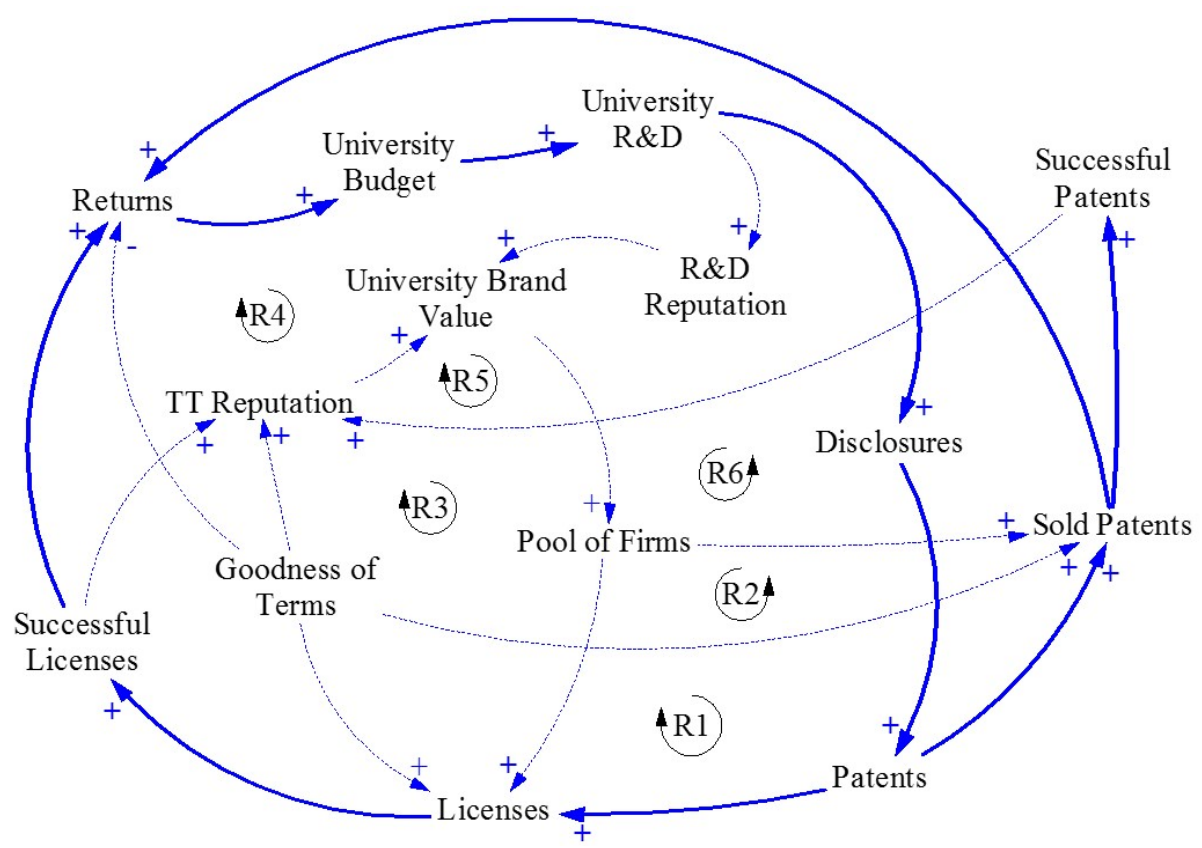

Issued patents are marketed by the TTO, leading to a certain amount of licenses. The number of licenses executed is not only a function of the number of patents, but also of the goodness of terms. The TTO and the licensee have disparate information about the value and commercialisation potential of the technology (Abramo et al., 2009; Vishwasrao, 1994). This information asymmetry accentuates the role the licensing terms play in the outcome of the negotiation (Gallini and Wright, 1990; Macho-Stadler and Pérez-Castrillo, 1991, 2010). The goodness of terms variable conceptually incorporates the licensing terms, such as royalty rates and milestone payments and the manner in which the TTO treats its industry partners during the licensing process. An increase in this variable means that the terms are becoming desirable from the perspective of the industry partner, leading to more successful negotiations and greater number of licenses executed. We should highlight that these are all nonlinear processes, which means that a detailed prediction of the system's behaviour is impossible solely based on its qualitative study.

Not all licenses will lead to a commercially successful product or service. In the US, the success rate is about $44 \%$ based on a ten year-average (Association of University Technology Managers, 2012). Again, we postulate that these behaviours are subject to scale within the system boundaries. The successful licenses will lead to a return to the university, feeding into the university budget, a part of which will feed into the university $R \& D$ budget. This represents the reinforcing feedback loop R1. Better goodness of terms increases the licensing rate, but on the other hand lowers the return per license due to relaxed licensing terms. This is modelled using a negative relationship.

In this section, we only evaluate licensing to an established company. Licensing to an entrepreneur is considered academic entrepreneurship and will be covered in Section 4.3. The university may increase revenue through royalties and fees, or receive equity in the 
company as the payment. Instead of licensing technologies, the TTO can also sell the patent rights to a company or an entrepreneur. Thus a portion of patents becomes sold patents and as previously explained for successful licenses, not all sold patents are commercially successful patents for the buyer. However, an increasing number of sold patents will lead to a greater amount of successful patents. The difference to the process on licenses is that the sold patents feed back into the university budget, because the buyer takes on the risk whether the technology is successful or not. This represents the reinforcing feedback loops R2.

As mentioned in Section 2, prestigious universities attract more corporate interactions (Siegel et al., 2004). We include this effect in our model via the variable $R \& D$ reputation. Sine et al. (2003) state that institutional prestige can be used to explain the number of licenses that exceed the number predicted by past performance and thus individual university heterogeneity. This leads to the postulate that there is a second type of reputation to consider, which is determined by the industry perception of university technology transfer activities, which we name the TT reputation. Siegel et al. (2003a) identified that $80 \%$ of company executives or entrepreneurs found that universities are too aggressive in exercising their IP rights. However, according to the same study, only $13.3 \%$ of the TTO directors and administrators think that they are too aggressive. This leads us to define a positive link between goodness of terms and TT reputation. Together, these two variables positively feed into the university brand value. This variable represents the overall value of the name and the prestige of a particular university from an innovation perspective. The $R \& D$ reputation variable does not reflect any technology transfer activities and it is solely it is only influenced by the university $R \& D$. On the other hand, the TT reputation is determined by the historical performance (successful licenses and successful patents) and the perceived current performance of the TTO, the goodness of terms.

With no limitation to any particular geographic region or industry, we codify three categories of firms as they relate to the UITT process: the total pool, or total number of firms $(P t)$; the pool of firms that are interested in technology transfer with universities $(P w)$, no matter if they are currently participating in the UITT process or not; and the pool of firms that actively participate in some form technology transfer with one or more universities $(P d)$. The relationship between the three pools is one of subsets, with the size of the pools $P d<P w<P t$, as shown in Figure 4.

Figure 4 Categorisation of companies (not proportional) (see online version for colours)

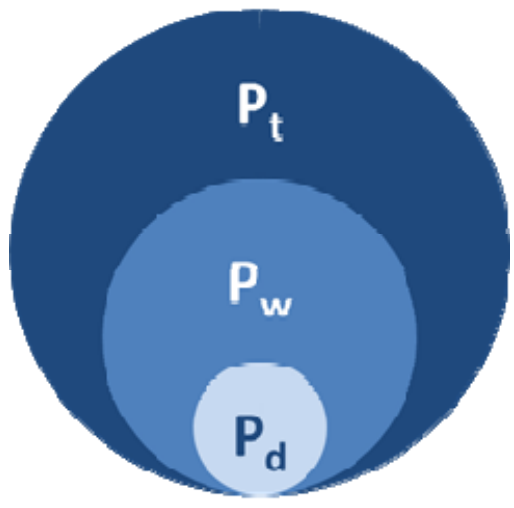


In a survey of members of the Licensing Executives Society (LES) in the US and Canada, Thursby and Thursby (2001) found that nearly half of the companies that responded ranked personal contacts between their R\&D staff and university personnel as extremely important. Yet less than $10 \%$ indicated that it was extremely important to them that their licensing staff routinely canvass universities for new technologies. This suggests that, while UITT is important for companies, much of the onus for disseminating knowledge about IP and building relationships rests with the TTOs. We postulate that universities can increase the likelihood of successful licensing negotiations by maintaining good relationships with industry, especially via fair goodness of terms. Furthermore, the number of companies attracted to willingly enter into a licensing deal with a university can be increased (i.e., an increase of $P w$ ). To quantify this effect, we created the variable pool of firms, which is mainly influenced by the university brand value.

The university brand value (as well as the preceding $T T$ reputation and $R \& D$ reputation on their own) and the pool of firms have to be treated as an asset to the university because they lead to competitive advantage (Prahalad, 1993; Wernerfelt, 1984). According to the VRIO framework to evaluate organisational resources (Barney, 1991, 1995), in order to lead to a competitive advantage, a resource has to be valuable, rare, costly to imitate and the firm has to be organised to capture the value of the resources. The four intangible assets we have identified meet the first three criteria. It takes a long time to build brand value and partnerships with industry. Due to the effort required in creating and maintaining successful partnerships, they are rare and costly to imitate. Thus to help set a university apart from others, the crucial point is to design the TTO organisation in a way to capture the value of these resources. By including these variables and the associated information flows, we generate more interrelations and the additional reinforcing feedback loops R3, R4, R5 and R6. These will be investigated in more detail in Section 5.

\subsection{Collaborative research}

Collaborative (or sponsored) research has been known for years as a means for the creation of new knowledge and IP (Steensma, 1996). There is a distinction between university $R \& D$ and collaborative research as it pertains to IP ownership. In terms of collaborative R\&D, the IP is usually owned by the industrial partner, or jointly and not available for commercialisation through the university (Jelinek and Markham, 2007).

The amount of collaborative research performed depends mainly on the pool of firms, which already reflects the university brand value and is an indicator of how attractive the university is and how well it is linked to industry and the goodness of terms. The better the terms offered by the university, the higher the probability that a contract will be signed and a collaboration will be started. For a university scientist, this has advantages over licensing revenue. The money goes directly into the research budget and the scientist are funded to conduct the research in a planned manner, instead of hoping on future royalty streams, which are less stable and predictable (Lee, 2000).

Collaborative research affects the TT reputation because it requires technology transfer between the university and a non-academic partner. It also affects the $R \& D$ reputation, because even if the innovations cannot be commercialised, it does increase the amount of research performed at the university, thus leading to more publications, presentations and articles that create more awareness in industry. Figure 5 shows two 
reinforcing loops related to these relationships, namely R7, capturing the impact of the TT reputation and $\mathrm{R} 8$, capturing the impact of the $R \& D$ reputation.

Figure 5 Influence diagram for collaborative research (see online version for colours)

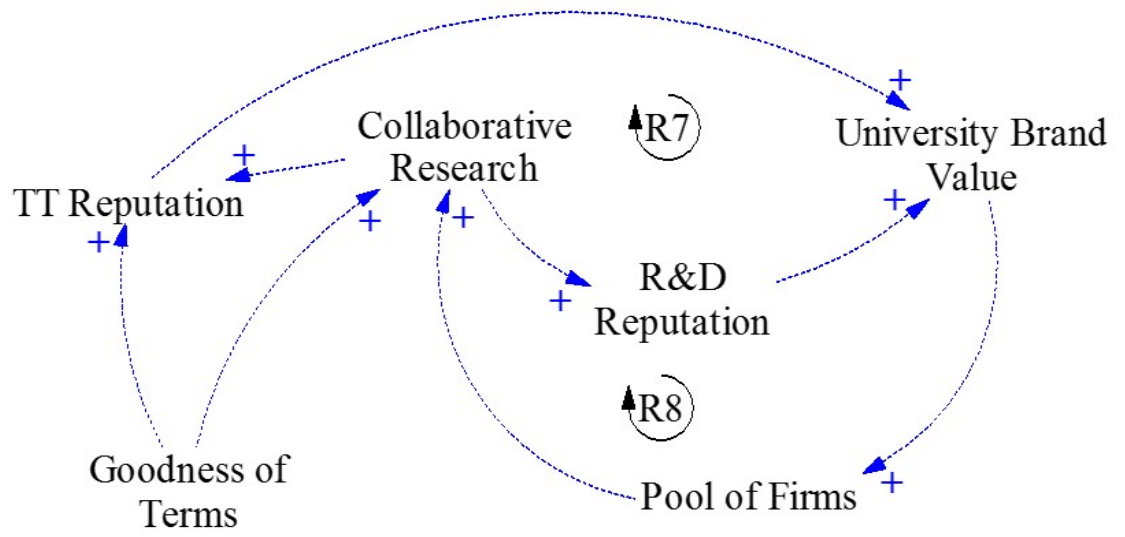

\subsection{Academic entrepreneurship}

A common type of academic entrepreneurship consists of licensing a technology to an independent entrepreneur. The process is very similar to the one described in Section 4.1, namely university $R \& D$ leads to disclosures and some of them become patents. In this process, patents will be licensed to a university start-up, generating returns, which feed back into the university budget to increase university $R \& D$. This constitutes reinforcing loop R9. As in previous processes, the TTO can influence this loop via the goodness of terms. Better terms positively affect the number of university start-ups, but result in lower returns per start-up.

There are two additional types of academic entrepreneurship, namely spin-offs from research parks (Löfsten and Lindelöf, 2002; Siegel et al., 2003c; Vedovello, 1997) and start-ups supported through incubators (Rasmussen et al., 2006). The latter is often associated with universities but not restricted to students (Wiggins and Gibson, 2003). Both can be financed, either wholly or partially through the university budget. Both student start-ups and spin-offs do not necessarily lead to direct returns and the TTO is not always involved in the management, process and policy design of these institutions.

The addition of industry perceptions (i.e., TT reputation, R\&D reputation) and associated information flows (e.g., flow affecting university brand value) increases the number of feedback loops. There is a direct reinforcing mechanism between university start-ups and the pool of firms (R10) as well as a broader feedback structure via an increase in $R \& D$ reputation due to increasing university $R \& D$ activities (R11). Additional feedback loops appear for student start-ups through the TT reputation (R12) and directly via the pool of firms (R13); for spin-offs via the TT reputation (R14) and the pool of firms (R15); and for the Research Park via the $R \& D$ reputation (R16). We will discuss these loops further in Section 5. 
Figure 6 Influence diagram for academic entrepreneurship (see online version for colours)

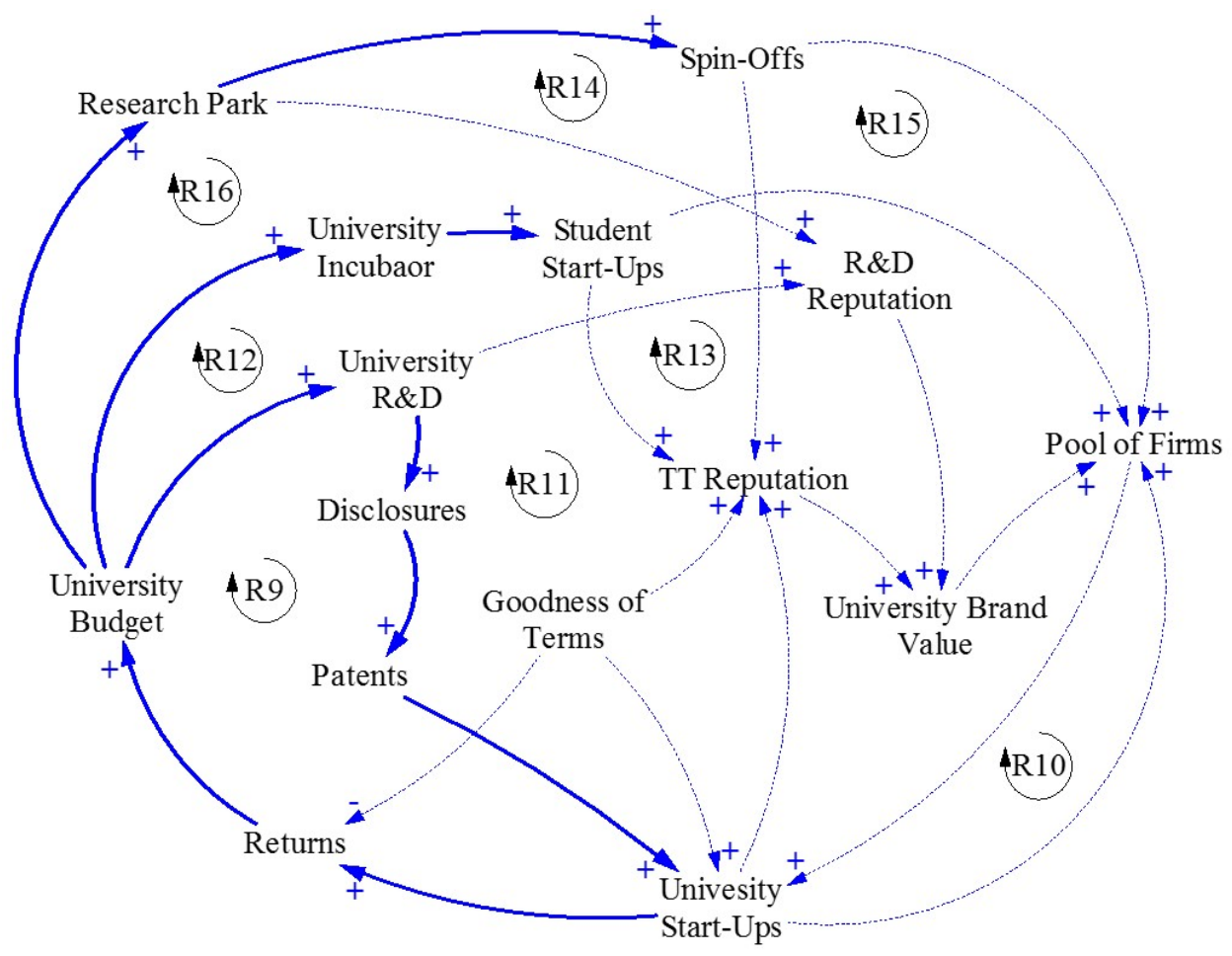

\subsection{Consulting}

Top research universities pride themselves on the reputation their faculty have as scientists at the cutting edge of their field and as invaluable sources of information and advice for companies. Firms, in turn, seek short-term support from highly qualified and reputable consultants, many times from universities (Perkmann and Walsh, 2008). In our systems dynamics model, the consulting variable, as well as the collaborative research variable, is dependent on the pool of firms.

Figure 7 Influence diagram for consulting (see online version for colours)

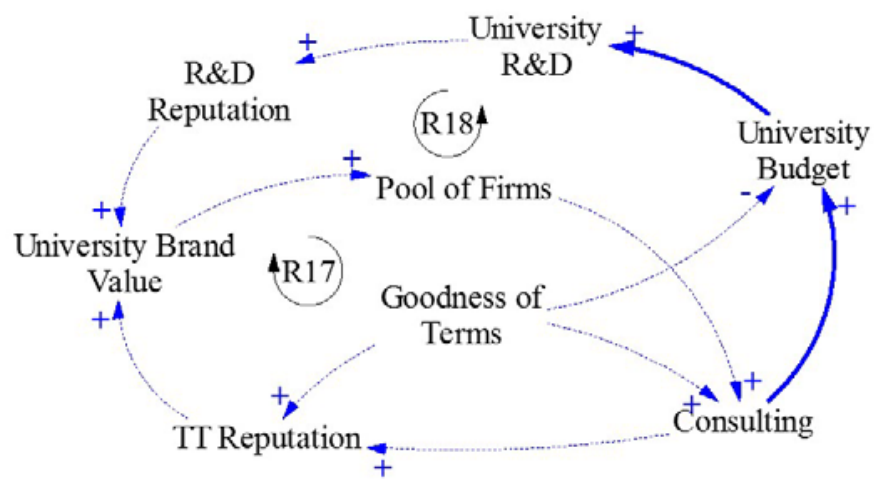


The returns from consulting, at least partially, feed back into the university budget and can be reinvested in university $R \& D$, under the premise that the academic consultant is not running a consulting firm on the side. In addition, their work impacts the TT reputation via positive industry experience with a faculty member. An extension to this model should incorporate faculty incentives. Frequently, university policies encourage private consulting agreements. Similarly to the collaborative research model, Figure 7 shows two reinforcing loops, R18 that captures the impact of the TT reputation and R17 that captures the impact of the $R \& D$ reputation.

\section{Findings}

The previous sections have explored and modelled four technology transfer channels between universities (i.e., their TTOs) and industry. Taking as a point of departure the traditional linear model of technology transfer (Bradley et al., 2013; Harmon et al., 1997), we have built an expanded model incorporating the four channels and their connection to industry perceptions. Table 1 provides an overview of the identified feedback loops that require special attention from a methodological point of view (Wolstenholme, 1990). We demonstrate with this overview that the TTO has at least a point of direct influence within each feedback loop. In most cases, feedback loops also include the variables capturing the industry perceptions of the TTO.

Table 1 Overview of feedback loops

\begin{tabular}{|c|c|c|c|}
\hline Loop & Name & Variables & Influenced by TTO \\
\hline $\mathrm{R} 1$ & $\begin{array}{c}\text { Licensing } \\
\text { process }\end{array}$ & $\begin{array}{l}\text { University R\&D, disclosures, } \\
\text { patents, licenses, successful } \\
\text { licenses, returns, university } \\
\text { budget }\end{array}$ & $\begin{array}{l}\text { Direct (goodness of terms) and } \\
\text { medium (direct and indirect via } \\
\text { pool of firms) }\end{array}$ \\
\hline $\mathrm{R} 2$ & $\begin{array}{l}\text { Selling } \\
\text { process }\end{array}$ & $\begin{array}{l}\text { University R\&D, disclosures, } \\
\text { patents, sold patents, successful } \\
\text { patents, returns, university } \\
\text { budget }\end{array}$ & $\begin{array}{l}\text { Direct (goodness of terms) and } \\
\text { medium (direct and indirect via } \\
\text { pool of firms) }\end{array}$ \\
\hline R3 & $\begin{array}{l}\text { TT rep } \\
\text { licensing }\end{array}$ & $\begin{array}{l}\text { Licenses, successful licenses, TT } \\
\text { reputation, university brand } \\
\text { value, pool of firms }\end{array}$ & $\begin{array}{l}\text { Direct (goodness of terms) and } \\
\text { strong (direct and UBV and pool } \\
\text { of firms are part of the loop) }\end{array}$ \\
\hline $\mathrm{R} 4$ & $\begin{array}{l}\text { R\&D rep } \\
\text { licensing }\end{array}$ & $\begin{array}{l}\text { University R\&D, R\&D } \\
\text { reputation, university brand } \\
\text { value, pool of firms, licenses, } \\
\text { successful licenses, returns, } \\
\text { university budget }\end{array}$ & $\begin{array}{l}\text { Direct (goodness of terms) and } \\
\text { strong (direct and pool of firms is } \\
\text { part of the loop) }\end{array}$ \\
\hline R5 & $\begin{array}{l}\text { TT rep } \\
\text { selling }\end{array}$ & $\begin{array}{l}\text { Sold patents, successful patents, } \\
\text { TT reputation, university brand } \\
\text { value, pool of firms }\end{array}$ & $\begin{array}{l}\text { Direct (goodness of terms) and } \\
\text { strong (direct and UBV and pool } \\
\text { of firms are part of the loop) }\end{array}$ \\
\hline R6 & $\begin{array}{l}\text { R\&D rep } \\
\text { selling }\end{array}$ & $\begin{array}{l}\text { University R\&D, R\&D } \\
\text { reputation, university brand } \\
\text { value, pool of firms, sold patents, } \\
\text { returns, university budget }\end{array}$ & $\begin{array}{l}\text { Direct (goodness of terms) and } \\
\text { strong (direct and UBV and pool } \\
\text { of firms are part of the loop) }\end{array}$ \\
\hline
\end{tabular}


Table 1 Overview of feedback loops (continued)

\begin{tabular}{|c|c|c|c|}
\hline Loop & Name & Variables & Influenced by TTO \\
\hline R7 & $\begin{array}{c}\text { TT rep } \\
\text { collaborating }\end{array}$ & $\begin{array}{l}\text { Collaborative research, TT } \\
\text { reputation, university brand } \\
\text { value, pool of firms }\end{array}$ & $\begin{array}{l}\text { Direct (goodness of terms) and } \\
\text { strong (direct and UBV and pool } \\
\text { of firms are part of the loop) }\end{array}$ \\
\hline $\mathrm{R} 8$ & $\begin{array}{l}\text { R\&D rep } \\
\text { collaborating }\end{array}$ & $\begin{array}{l}\text { Collaborative research, } R \& D \\
\text { reputation, university brand } \\
\text { value, pool of firms }\end{array}$ & $\begin{array}{l}\text { Direct (goodness of terms) and } \\
\text { strong (direct and UBV and pool } \\
\text { of firms are part of the loop) }\end{array}$ \\
\hline R9 & $\begin{array}{l}\text { U start-up } \\
\text { process }\end{array}$ & $\begin{array}{l}\text { University R\&D, disclosures, } \\
\text { patents, university spin-offs, } \\
\text { returns, university budget }\end{array}$ & $\begin{array}{l}\text { Direct (goodness of terms) and } \\
\text { medium (direct and indirect via } \\
\text { pool of firms) }\end{array}$ \\
\hline R10 & $\begin{array}{l}\text { Reinforcing } \\
\text { U start-up }\end{array}$ & $\begin{array}{l}\text { University start-ups, pool of } \\
\text { firms }\end{array}$ & $\begin{array}{l}\text { Direct (goodness of terms) and } \\
\text { strong (direct and pool of firms } \\
\text { are part of the loop) }\end{array}$ \\
\hline R11 & $\begin{array}{l}\text { R\&D rep U } \\
\text { start-up }\end{array}$ & $\begin{array}{l}\text { University R\&D, R\&D } \\
\text { reputation, university brand } \\
\text { value, pool o firms, university } \\
\text { start-ups, returns, university } \\
\text { budget }\end{array}$ & $\begin{array}{l}\text { Direct (goodness of terms) and } \\
\text { strong (direct and UBV and pool } \\
\text { of firms are part of the loop) }\end{array}$ \\
\hline $\mathrm{R} 12$ & $\begin{array}{l}\text { TT rep S } \\
\text { start-up }\end{array}$ & $\begin{array}{l}\text { University budget, university } \\
\text { incubator, student start-ups, TT } \\
\text { reputation, university brand } \\
\text { value, pool of firms, university } \\
\text { start-ups, returns }\end{array}$ & $\begin{array}{l}\text { Direct (goodness of terms) and } \\
\text { strong (direct and UBV and pool } \\
\text { of firms are part of the loop) }\end{array}$ \\
\hline R13 & $\begin{array}{l}\text { Pool S } \\
\text { start-up }\end{array}$ & $\begin{array}{l}\text { University budget, university } \\
\text { incubator, student start-ups, pool } \\
\text { of firms, university start-ups, } \\
\text { returns }\end{array}$ & $\begin{array}{l}\text { Direct (goodness of terms) and } \\
\text { strong (direct and pool of firms } \\
\text { are part of the loop) }\end{array}$ \\
\hline R14 & $\begin{array}{l}\text { TT rep spin- } \\
\text { off }\end{array}$ & $\begin{array}{l}\text { University budget, research park, } \\
\text { spin-offs, TT reputation, } \\
\text { university brand value, pool of } \\
\text { firms, university start-ups, } \\
\text { returns }\end{array}$ & $\begin{array}{l}\text { Direct (goodness of terms) and } \\
\text { strong (direct and UBV and pool } \\
\text { of firms are part of the loop) }\end{array}$ \\
\hline $\mathrm{R} 15$ & Pool spin-off & $\begin{array}{l}\text { University budget, research park, } \\
\text { spin-offs, pool of firms, } \\
\text { university start-ups, returns }\end{array}$ & $\begin{array}{l}\text { Direct (goodness of terms) and } \\
\text { strong (direct and UBV and pool } \\
\text { of firms are part of the loop) }\end{array}$ \\
\hline $\mathrm{R} 16$ & $\begin{array}{l}\text { R\&D rep } \\
\text { research park }\end{array}$ & $\begin{array}{l}\text { University budget, research park, } \\
\text { R\&D reputation, university } \\
\text { brand value, pool of firms, } \\
\text { university start-ups, returns }\end{array}$ & $\begin{array}{l}\text { Direct (goodness of terms) and } \\
\text { strong (direct and UBV and pool } \\
\text { of firms are part of the loop) }\end{array}$ \\
\hline R17 & $\begin{array}{l}\text { TT rep } \\
\text { consulting }\end{array}$ & $\begin{array}{l}\text { Consulting, TT reputation, } \\
\text { university brand value, pool of } \\
\text { firms }\end{array}$ & $\begin{array}{l}\text { Direct (goodness of terms) and } \\
\text { strong (direct and UBV and pool } \\
\text { of firms are part of the loop) }\end{array}$ \\
\hline $\mathrm{R} 18$ & $\begin{array}{l}\text { R\&D rep } \\
\text { consulting }\end{array}$ & $\begin{array}{l}\text { Consulting, university budget, } \\
\text { university } R \& D, R \& D \\
\text { reputation, university brand } \\
\text { value, pool of firms }\end{array}$ & $\begin{array}{l}\text { Direct (goodness of terms) and } \\
\text { strong (direct and UBV and pool } \\
\text { of firms are part of the loop) }\end{array}$ \\
\hline
\end{tabular}

However, if we exclude the industry perception, the number of feedback loops in the model decreases to three, as the TTO would revert to primarily focus on direct revenue generation. This would limit its focus on the four intangible assets identified and shorten 
its planning horizon. Attending to the findings reported by Siegel et al. (2004) and Sine et al. (2003), shunning industry perception would be an act of negligence on the part of the university. Figure 8 combines the four models into one unified model, providing a holistic view of the UITT process from the perspective of the TTO. In this more complex model (Figure 8), the impacts of the goodness of terms, the TT reputation and the pool of firms stand out as pivotal for the success of a TTO and a university technology transfer process.

Figure 8 Influence diagram for comprehensive UITT model (see online version for colours)

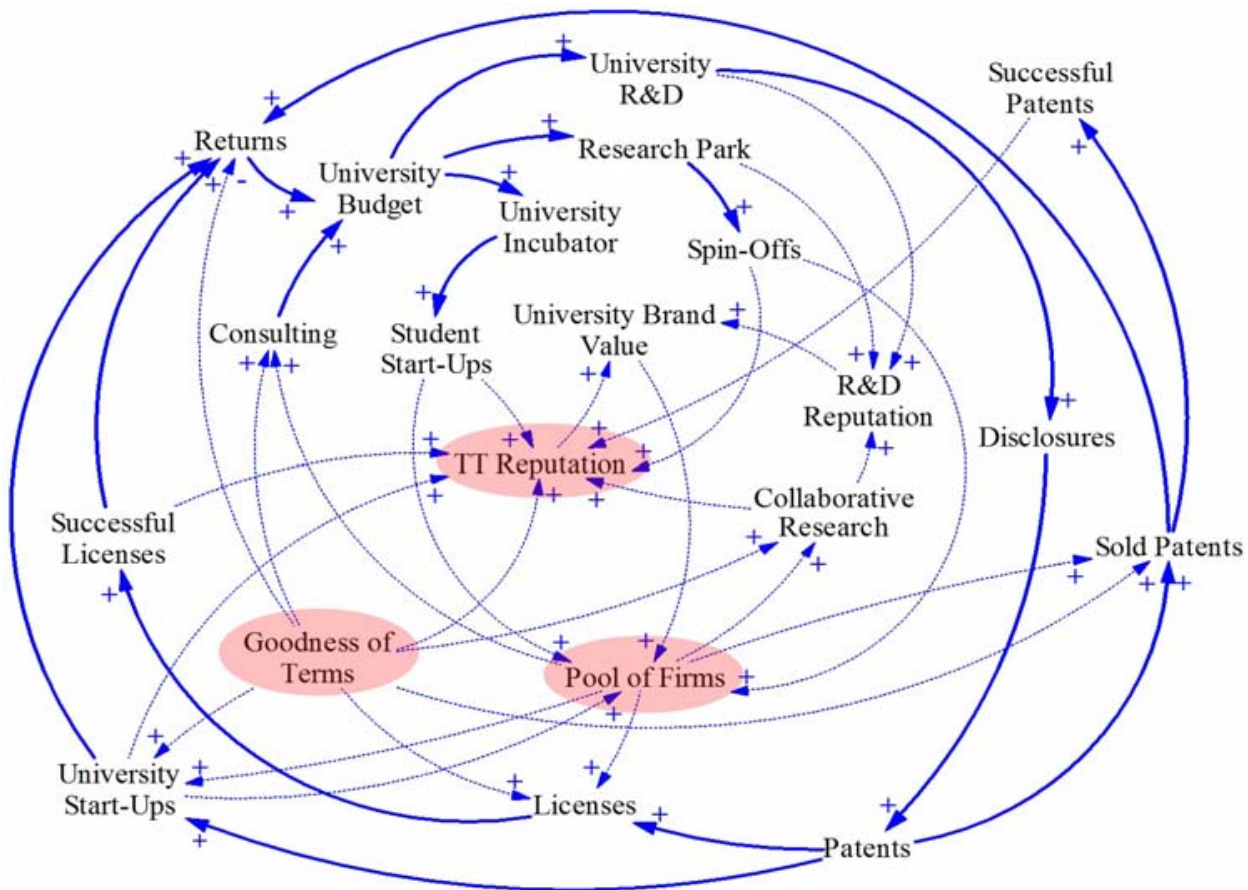

The various technology transfer channels are tied together through these constructs. TTO managers have to take these factors into consideration in order to improve their processes and policies. The fact that these technology transfer channels are tied together leads to the inevitable conclusion that a TTO needs a well-defined overall technology transfer strategy as the baseline for the design of more specific policies and processes. The system dynamics perspective indicates that, due to the interconnection of different technology transfer channels, it is impossible to achieve optimal returns to the university without an overall UITT strategy.

Because the university brand value and the pool of firms are part of many feedback loops and the TTO influences these via the perceived goodness of terms, a relaxation of terms and policies that encourage greater industry interaction, less bureaucracy and simpler processes should be evaluated. Although relaxing goodness of terms may harm short-term profits, in the long run it may result in a better revenue position for the university. A growth in the pool of firms and other revenue channels such as collaborative research, consulting and academic entrepreneurship will give the university a competitive advantage when competing for research funding and industry 
partnerships. Another (unintended) consequence we identify with this theoretical model is the fostering of economic growth through innovation and job creation due to increased entrepreneurial activities within the university's regional business ecosystem.

\section{Discussion}

As Bradley et al. (2013) anticipated, the traditional linear technology transfer process is outdated and includes too many shortcomings and inaccuracies. The overemphasis on patents and licensing will not lead to optimal returns for university TTOs. By modelling additional technology transfer and potential revenue channels, we have conceived a broader inclusive theoretical model that can allow for developing a more strategic framework for university TTOs. The application of systems dynamic theory (Forrester, 2007) permits the shift from the traditional revenue-maximisation focus to a comprehensive understanding of the dynamics leading to successful UITT. Our model contributes a broader theoretical perspective, attending to implicit and explicit interactions between the process' stakeholders (Hill and Jones, 1992) and accounting for perceptions of universities' technology transfer reputation, all of which are currently lacking in linear models.

The most successful universities in terms of start-up activity set themselves apart by having a well-defined strategy and using external entrepreneurs, rather than academic entrepreneurs (Lockett et al., 2003). However, this strategy inherently goes beyond the boundaries of the TTO or requires a redefinition of the roles and responsibilities of a university TTO. And there are additional issues that should concern the TTO but are beyond its oversight. Academic scientists, especially those without tenure, are under a lot of pressure to publish their ideas and innovations. Following the tenure policies of their universities, they publish in certain research journals or give presentations at leading conferences. They strive for peer recognition and a growing academic network (Siegel et al., 2007). Policies have to give credit for faculty involvement in technology transfer activities and compensate the possible publication delays caused by industry partnerships resulting in work that is undergoing patent applications. Commonly, these decisions are out of the control range of the TTO management, but rather rest with the academic leadership of the university.

Another aspect worth mentioning is the innovation ecosystem and the local entrepreneurial culture in which a university is embedded. Successful entrepreneurial regions, such as Silicon Valley or the Boston area, are not only characterised by a great availability of venture capital, but also by supporting institutions, formal and informal networks, as well as mentoring. Technology transfer opportunities emerge from these networks at a much greater rate than stand-alone university campuses. In particular, informal networks have been recognised as very important (Siegel et al., 2004). Furthermore, the culture can affect the type of commercialisation route chosen and can foster entrepreneurship. The university cannot change the entrepreneurial climate or build this entire infrastructure on its own, but it plays an important role in enabling it. This outlines the bigger picture that TTOs can use to evaluate policies during the development and implementation phases based on their region's entrepreneurial maturity.

There are also challenges the TTO faces on its own. Even though relaxing licensing terms would improve its reputation, the TTO must ensure a revenue stream for the university. In line with their overall strategy, TTOs need to strike a balance between 
lowering barriers with better IP licensing terms and policies on the one hand and getting adequate compensation for promising technologies on the other hand. Despite the forthright appeal of the resource-based approach, the TTO has to ensure that the organisation is structured in a way that permits realising the value of intangible assets (Barney, 1991; Dierickx and Cool, 1989; Wernerfelt, 1984).

TTOs need to be involved in more than just disclosing, patenting and licensing innovations if they are to help universities expand the impact of the UITT process. University executives and TTO managers cannot ignore the interconnections among technology transfer channels and factors such as goodness of terms, TT reputation and pool of firms if they aim to improve their processes and policies. TTOs interested in incorporating the proposed systems dynamics model into the technology licensing and commercialisation strategies should evaluate their current licensing model and quantify their level of those elements of the model not considered on their strategy (e.g., their TT reputation or university brand value). They should identify objectives aimed to boosting their reputation (e.g., via sponsored research), the size of the pool of firms and the goodness of terms, identifying and analysing adequate metrics. Finally, TTOs should act on those elements of the model under their purview (e.g., creation of student start-ups, goodness of licensing terms) to foster the evolution of their policies and operations in the desired direction.

\section{Conclusions and further research}

This paper marks a major step in theory development and modelling of the UITT process. Using a qualitative system dynamics approach, we provide a theoretical model that exemplifies the inherent complexity of the UITT process, a step forward from the empirical surveys that have been performed in this area. Our systems dynamics model shows that a technology transfer approach using the linear model yields a focus on short-term revenue maximisation and suboptimal benefits for the university as it disregards crucial dynamic relations. Applying a resource-based view of the UITT process, we accounted for factors such as the university brand value, the TT reputation and the pool of firms, demonstrating that different technology transfer channels are tightly coupled and have to be evaluated in unison for improving UITT returns. The theory developed in this paper identifies implicit and explicit processes across multiple stakeholders affecting the UITT. This theory suggests that technology transfer research should abandon the linear, agent-centred, revenue maximisation approach in favour of a system dynamics approach, inclusive of all stakeholders and implicit processes.

The theoretical model we present in this paper is not without limitations. Every model must have boundaries. External factors such as the market demand for a particular technology and rare events such as the case of disruptive 'homerun' technologies have not been included in this first order model. Additionally, to exploit the power that system dynamics offers as a modelling technique for the UITT process, delays and time effects have to be taken into consideration. This is not only important for the secondary dynamics and the time lags, but also to evaluate timing of revenue streams for the university. Understanding when the effect might be measurable is just as important as the magnitude of the effect. Further limitations include factors not incorporated in the current model are the size of the university, the geographical proximity to industries and the 
existence of an entrepreneurship-friendly ecosystem. These elements of the model may lead to more detailed inquiry as quantitative simulations are developed.

The findings suggest that a broad strategic view of the UITT process can be a major driver of greater university returns and requires policies counter to short-term licensing revenue maximisation seen with a traditional linear model of technology transfer. While the policy choices may be clear with this model for improving university returns, the fact remains that the ownership of the policies may remain outside of the TTOs management sphere. In some universities they lie with business affairs, research, academic affairs, or other administrative units. As a result, successful policy changes may be difficult, especially if the TTO continues to be measured on traditional short-term metrics by university leadership.

We are working towards an applied extension of this system dynamics model. One objective of this follow-on work will be to quantify the potential differences in returns to universities under differing policy regimes and attempt to optimise the returns based on changes to the main variables the TTO controls. A comparison between different universities from various regions will help evaluating political conditions, university strategies, as well as TTO policies and serve as case studies for validating the model.

\section{References}

Abramo, G., D'Angelo, C.A., Di Costa, F. and Solazzi, M. (2009) 'University-industry collaboration in Italy: a bibliometric examination', Technovation, Vol. 29, No. 6, pp.498-507.

Aldridge, T. and Audretsch, D.B. (2010) 'Does policy influence the commercialization route? Evidence from National Institutes of Health funded scientists', Research Policy, Vol. 39, No. 5, pp.583-588.

Anderson, T.R., Daim, T.U. and Lavoie, F.F. (2007) 'Measuring the efficiency of university technology transfer', Technovation, Vol. 27, No. 5, pp.306-318.

Association of University Technology Managers (2012) AUTM U.S. Licensing Activity Survey: FY2011, Association of University Technology Managers, Deerfield.

Association of University Technology Managers (2014) AUTM U.S. Licensing Activity Survey: FY2013, Association of University Technology Managers, Deerfield.

Balakrishnan, S. and Koza, M.P. (1993) 'Information asymmetry, adverse selection and joint-ventures: theory and evidence', Journal of Economic Behaviour\& Organization, Vol. 20, No. 1, pp.99-117.

Barney, J.B. (1991) 'Firm resources and sustained competitive advantage', Journal of Management, Vol. 17, No. 1, pp.99-120.

Barney, J.B. (1995) 'Looking inside for competitive advantage', The Academy of Management Executive, Vol. 9, No. 4, pp.49-61.

Baycan, T. and Stough, R.R. (2013) 'Bridging knowledge to commercialization: the good, the bad, and the challenging', Annals of Regional Science, Vol. 50, No. 2, pp.367-405.

Bercovitz, J. and Feldmann, M. (2006) 'Entpreprenerial universities and technology transfer: a conceptual framework for understanding knowledge-based economic development', Journal of Technology Transfer, Vol. 31, No. 1, pp.175-188.

Bercovitz, J.E., Feldman, M.P., Feller, I. and Burton, R. (2001) 'Organizational structure as a determinant of academic patent and licensing behaviour: an exploratory study of Duke, Johns Hopkins, and Pennsylvania State Universities', The Journal of Technology Transfer, Vol. 26, Nos. 1-2, pp.21-35.

Bradley, S.R., Hayter, C.S. and Link, A.N. (2013) 'Models and methods of university technology transfer', Foundations and Trends in Entrepreneurship, Vol. 9, No. 6, pp.571-650. 
Carlsson, B. and Fridh, A.C. (2002) 'Technology transfer in United States universities', Journal of Evolutionary Economics, Vol. 12, Nos. 1-2, pp.199-232.

Chapple, W., Lockett, A., Siegel, D.S. and Wright, M. (2005) 'Assessing the relative performance of U.K. university technology transfer offices: parametric and non-parametric evidence', Research Policy, Vol. 34, No. 3, pp.369-384.

Chesbrough, H. (2006) Open Innovation, Harvard Business Review Press, Boston.

Clarysse, B., Tartari, V. and Salter, A. (2011) 'The impact of entrepreneurial capacity, experience and organizational support on academic entrepreneurship', Research Policy, Vol. 40, No. 8 , pp.1084-1093.

Cohen, W.M. and Levinthal, D.A. (1990) 'Absorptive capacity: a new perspective on learning and innovation', Administrative Science Quarterly, Vol. 35, No. 1, pp.128-152.

Cohen, W.M., Nelson, R.R. and Walsh, J.P. (2002) 'Links and impacts: the influence of public research on industrial R\&D', Management Science, Vol. 48, No. 1, pp.1-23.

Coyle, R.G. (1996) System Dynamics Modelling: A Practical Approach, Vol. 1, CRC Press, Boca Raton.

Coyle, R.G. (1998) 'The practice of system dynamics: milestones, lessons and ideas from 30 years experience', System Dynamics Review, Vol. 14, No. 4, pp.343-365.

Dierickx, I. and Cool, K. (1989) 'Asset stock accumulation and sustainability of competitive advantage', Management Science, Vol. 35, No. 12, pp.1504-1511.

Eisenhardt, K.M. (1989) 'Agency theory: an assessment and review', Academy of Management Review, Vol. 14, No. 1, pp.57-74.

Forrester, J.W. (1961) Industrial Dynamics, MIT Press, Cambridge.

Forrester, J.W. (1968) Principles of Systems, Pegasus Communications, Waltham.

Forrester, J.W. (2007) 'System dynamics - the next fifty years', System Dynamics Review, Vol. 23, Nos. 2-3, pp.359-370.

Friedman, J. and Silberman, J. (2003) 'University technology transfer: do incentives, management, and location matter?', The Journal of Technology Transfer, Vol. 28, No. 1, pp.17-30.

Gallini, N.T. and Wright, B.D. (1990) 'Technology transfer under asymmetric information', The Rand Journal of Economics, Vol. 21, No. 1, pp.147-160.

Harmon, B., Ardishvili, A., Cardozo, R., Elder, T., Leuthold, J., Parshall, J. and Smith, D. (1997) 'Mapping the university technology transfer process', Journal of Business Venturing, Vol. 12 , No. 6, pp.423-434.

Hayter, C.S. (2011) 'In search of the profit-maximizing actor: motivations and definitions of success from nascent academic entrepreneurs', The Journal of Technology Transfer, Vol. 36, No. 3, pp.340-352.

Hill, C.W. and Jones, T.M. (1992) 'Stakeholder agency theory', Journal of Management Studies, Vol. 29, No. 2, pp.131-154.

Jelinek, M. and Markham, S. (2007) 'Industry-university IP relations: integrating perspectives and policy solutions', IEEE Transactions on Engineering Management, Vol. 54, No. 2, pp.257-267.

Jensen, R.A. and Thursby, M.C. (2001) 'Proofs and prototypes for sale: the licensing of university inventions', The American Economic Review, Vol. 91, No. 1, pp.240-259.

Jensen, R.A., Thursby, J.G. and Thursby, M.C. (2003) 'Disclosure and licensing of university inventions: the best we can do with the $\mathrm{s}^{* *} \mathrm{t}$ we get to work with', International Journal of Industrial Organization, Vol. 21, No. 9, pp.1271-1300.

Kealey, T. and Nelson, R.R. (1996) The Economic Laws of Scientific Research, Macmillan, London.

Kim, Y. (2011) 'The ivory tower approach to entrepreneurial linkage: productivity changes in university technology transfer', The Journal of Technology Transfer, Vol. 38, No. 2, pp.180-197. 
Lee, Y.S. (2000) 'The sustainability of university-industry research collaboration: an empirical assessment', The Journal of Technology Transfer, Vol. 25, No. 2, pp.111-133.

Lerner, J. (2005) 'The university and the start-up: lessons from the past two decades', The Journal of Technology Transfer, Vol. 30, Nos. 1-2, pp.49-56.

Link, A.N. and Scott, J.T. (2005) 'Universities as partners in US research joint ventures', Research Policy, Vol. 34, No. 3, pp.385-393.

Litan, R.E., Mitchell, L. and Reedy, E.J. (2007) 'The university as innovator: bumps in the road', Issues in Science \& Technology, Vol. 23, No. 4, pp.57-66.

Lockett, A., Wright, M. and Franklin, S. (2003) 'Technology transfer and universities' spin-out strategies', Small Business Economics, Vol. 20, No. 2, pp.185-200.

Löfsten, H. and Lindelöf, P. (2002) 'Science parks and the growth of new technology-based firms academic-industry links, innovation and markets', Research Policy, Vol. 31, No. 6, pp.859-876.

Lowe, R.A. (2006) 'Who develops a university invention? The impact of tacit knowledge and licensing policies', The Journal of Technology Transfer, Vol. 31, No. 4, pp.415-429.

Macho-Stadler, I. and Pérez-Castrillo, D. (1991) 'Contrats de licences etasymétried' information', Annalesd'Economie et de Statistique, Vol. 24, pp.189-208.

Macho-Stadler, I. and Pérez-Castrillo, D. (2010) 'Incentives in university technology transfers', International Journal of Industrial Organization, Vol. 28, No. 4, pp.362-367.

Markman, G.D., Gianiodis, P.T., Phan, P.H. and Balkin, D.B. (2005) 'Innovation speed: transferring university technology to market', Research Policy, Vol. 34, No. 1, pp.1058-1075.

Martinelli, A., Meyer, M. and von Tunzelmann, N. (2008) 'Becoming an entrepreneurial university? A case study of knowledge exchange relationships and faculty attitudes in a medium-sized, research-oriented university', The Journal of Technology Transfer, Vol. 33, No. 3, pp. 259-283.

Nelson, R.R. (1959) 'The simple economics of basic scientific research', Journal of Political Economy, Vol. 67, No. 3, pp.297-306.

O'Shea, R.P., Allen, T.J., Chevalier, A. and Roche, F. (2005) 'Entrepreneurial orientation, technology transfer and spinoff performance of US universities', Research Policy, Vol. 34, No. 7, pp.994-1009.

Owen-Smith, J. and Powell, W.W. (2001) 'To patent or not: faculty decisions and institutional success at technology transfer', The Journal of Technology Transfer, Vol. 26, Nos. 1-2, pp.99-114.

Parunak, H.V.D., Savit, R. and Riolo, R.L. (1998) 'Agent-based modeling vs. equation-based modeling: a case study and users' guide', in Sichman, J.S. et al. (Eds.): Multi-Agent Systems and Agent-Based Simulation, pp.10-25, Springer, Berlin.

Perkmann, M. and Walsh, K. (2008) 'Engaging the scholar: three types of academic consulting and their impact on universities and industry', Research Policy, Vol. 37, No. 10, pp.1884-1891.

Pidd, M. (2004) Computer Simulation in Management Science, $5^{\text {th }}$ ed., John Wiley \& Sons, Chichester.

Pidd, M. (2009) Tools for Thinking: Modeling in Management Science, 3rd ed., John Wiley \& Sons, Chichester.

Prahalad, C.K. (1993) 'The role of core competencies in the corporation', Research-Technology Management, Vol. 36, No. 6, pp.40-47.

Rasmussen, E., Moen, Ø. and Gulbrandsen, M. (2006) 'Initiatives to promote commercialization of university knowledge', Technovation, Vol. 26, No. 4, pp.518-533.

Richardson, G.P. (1999) Feedback Thought in Social Science and Systems Theory, Pegasus Communications, Waltham.

Richardson, G.P. (2011) 'Reflections on the foundations of system dynamics', System Dynamics Review, Vol. 27, No. 3, pp.219-243. 
Rogers, E.M., Takegami, S. and Yin, J. (2001) 'Lessons learned about technology transfer', Technovation, Vol. 21, No. 4, pp.253-261.

Santoro, M.D. (2000) 'Success breeds success: the linkage between relationship intensity and tangible outcomes in industry-university collaborative ventures', The Journal of High Technology Management Research, Vol. 11 No. 2, pp.255-273.

Schmoch, U. (1999) 'Interaction of universities and industrial enterprises in Germany and the United States - a comparison', Industry and Innovation, Vol. 6, No. 1, pp.51-68.

Shane, S. (2004) 'Encouraging university entrepreneurship? The effect of the Bayh-Dole act on university patenting in the United States', Journal of Business Venturing, Vol. 19, No. 1, pp.127-151.

Siegel, D.S. (2013) 'Academic entrepreneurship: lessons learned for university administrators and policymakers', in Audretsch, D.B. and Lindenstein Walshok, M. (Eds.): Creating Competitiveness: Entrepreneurship and Innovation Policies for Growth, pp.116-135, Edward Elgar Publishing, Glos.

Siegel, D.S. and Phan, P.H. (2005) 'Analyzing the effectiveness of university technology transfer: implications for entrepreneurship education', in Liebcap, G. (Ed.): Advances in the Study of Entrepreneurship, Innovation, and Economic Growth, pp.1-38, Elsevier Science/JAI Press, Amsterda.

Siegel, D.S., Veugelers, R. and Wright, M. (2007) 'Technology transfer offices and commercialization of university intellectual property: performance and policy implications', Oxford Review of Economic Policy, Vol. 23, No. 4, pp.640-660.

Siegel, D.S., Waldman, D.A., Atwater, L.E. and Link, A.N. (2003a) 'Commercial knowledge transfers from universities to firms: improving the effectiveness of university-industry collaboration', Journal of High Technology Management Research, Vol. 14, No. 1, pp.111-133.

Siegel, D.S., Waldman, D.A. and Link, A.N. (2003b) 'Assessing the impact of organizational practices on the relative productivity of university technology transfer offices: an exploratory study', Research Policy, Vol. 32, No. 1, pp.27-48.

Siegel, D.S., Westhead, P. and Wright, M. (2003c) 'Assessing the impact of university science parks on research productivity: exploratory firm-level evidence from the United Kingdom', International Journal of Industrial Organization, Vol. 21, No. 9, pp.1357-1369.

Siegel, D.S., Waldman, D.A., Atwater, L.E. and Link, A.N. (2004) 'Toward a model of the effective transfer of scientific knowledge from academicians to practitioners: qualitative evidence from the commercialization of university technologies', Journal of Engineering and Technology Management, Vol. 21, Nos. 1-2, pp.115-142.

Sine, W.D., Shane, S. and Di Gregorio, D. (2003) 'The halo effect and technology licensing: the influence of institutional prestige on the licensing of university inventions', Management Science, Vol. 49, No. 4, pp.478-496.

Steensma, H.K. (1996) 'Acquiring technological competencies through inter-organizational collaboration: an organizational learning perspective', Journal of Engineering and Technology Management, Vol. 12, No. 4, pp.267-286.

Steffensen, M., Rogers, E.M. and Speakman, K. (2000) 'Spin-offs from research centers at a research university', Journal of Business Venturing, Vol. 15, No. 1, pp.93-111.

Sterman, J.D. (2000) Business Dynamics, McGraw-Hill/Irwin, New York.

Swamidass, P.M. and Vulasa, V. (2009) 'Why university inventions rarely produce income? Bottlenecks in university technology transfer', The Journal of Technology Transfer, Vol. 34, No. 4, pp.343-363.

Thursby, J.G. and Kemp, S. (2002) 'Growth and productive efficiency of university intellectual property licensing', Research Policy, Vol. 31, No. 1, pp.109-124.

Thursby, J.G. and Thursby, M.C. (2001) 'Industry perspectives on licensing university technologies: sources and problems', Industry and Higher Education, Vol. 15, No. 4, pp.289-294. 
Thursby, J.G. and Thursby, M.C. (2002) 'Who is selling the ivory tower? Sources of growth in university licensing', Management Science, Vol. 48, No. 1, pp.90-104.

Thursby, J.G. and Thursby, M.C. (2003) 'Industry/university licensing: characteristics, concerns and issues from the perspective of the buyer', The Journal of Technology Transfer, Vol. 28, Nos. 3-4, pp.207-213.

Vedovello, C. (1997) 'Science parks and university-industry interaction: geographical proximity between the agents as a driving force', Technovation, Vol. 17, No. 9, pp.491-531.

Vishwasrao, S. (1994) 'Intellectual property rights and the mode of technology transfer', Journal of Development Economics, Vol. 44, No. 2, pp.381-402.

Wernerfelt, B. (1984) 'A resource-based view of the firm', Strategic Management Journal, Vol. 5, No. 2, pp.171-180.

Wiggins, J. and Gibson, D.V. (2003) 'Overview of US incubators and the case of the Austin technology incubator', International Journal of Entrepreneurship and Innovation Management, Vol. 3, Nos. 1-2, pp.56-66.

Wolstenholme, E.F. (1990) System Enquiry: A System Dynamics Approach, John Wiley \& Sons, Chichester.

Wright, M., Clarysse, B., Mustar, P. and Lockett, A. (2007) Academic Entrepreneurship in Europe, Edward Elger Publishing, Cheltenham. 